\title{
TRL ASSESSMENT OF SOLAR SAIL TECHNOLOGY DEVELOPMENT FOLLOWING THE 20-METER SYSTEM GROUND DEMONSTRATOR HARDWARE TESTING
}

\author{
Edward E. (Sandy) Montgomery, Roy M. Young \\ NASA Marshall Space Flight Center, Huntsville, AL, 35812 \\ Charles L. Adams \\ Gray Research, Inc., Huntsville, AL, 35806
}

\begin{abstract}
The NASA In-Space Propulsion Technology (ISPT) Projects Office has been sponsoring 2 separate, independent system design and development hardware demonstration activities during 2002-2005. ATK Space Systems of Goleta, CA was the prime contractor for one development team and L'Garde, Inc. of Tustin, CA was the prime contractor for the other development team. The goal of these activities was to advance the technology readiness level (TRL) of solar sail propulsion from 3 towards 6 by the year 2006. Component and subsystem fabrication and testing were completed successfully, including the ground deployment of 10 -meter and 20 -meter ground demonstration hardware systems under vacuum conditions. The deployment and structural testing of the 20-meter solar sail systems was conducted in the 30 meter diameter Space Power Facility thermal-vacuum chamber at NASA Glenn Plum Brook in April though August, 2005. This paper will present the results of the TRL assessment following the solar sail technology development activities associated with the design, development, analysis and testing of the 20-meter system ground demonstrators. Descriptions of the system designs for both the ATK and L'Garde systems will be presented. Changes, additions and evolution of the system designs will be highlighted. A description of the modeling and analyses activities performed by both teams, as well as testing conducted to raise the TRL of solar sail technology will be presented. A summary of the results of model correlation activities will be presented. Finally, technology gaps identified during the assessment and gap closure plans will be presented, along with "lessons learned", subsequent planning activities and validation flight opportunities for solar sail propulsion technology.
\end{abstract}

\section{INTRODUCTION}

NASA's ISPT goal is the advancement of key transportation technologies that will enable or enhance future robotic science and deep space exploration missions. At the program's inception, a set of technology investment priorities were established using a NASA-wide prioritization process and, for the most part, these priorities have changed little-thus allowing a consistent framework in which to fund and manage technology development. Technologies in the portfolio include aerocapture, advanced chemical propulsion, solar electric propulsion, and solar sail propulsion (SSP). Through a Research Opportunities in Space Science (ROSS) NASA Research Announcements (NRA) announcement in 2002 contracts for solar sail technology development were awarded to a team headed by L'Garde Inc., and another team lead by ATK Space Systems. The contracts were awarded to independently design, develop and test system ground demonstrator hardware. 10-meter- quadrants/ systems were fabricated and tested in 2004. Higher fidelity systems were produced and tested in 2005 during the third phase of the contract. The L'Garde team included Ball Aerospace (system integration and ACS design/ test), JPL (systems analysis), and LaRC (modeling, structural testing). The ATK team included SRS Technologies (sail provider), LaRC (modeling, structural testing), Arizona State University and Princeton Satellite Systems (attitude control system modeling, design) and MSFC for materials testing.

Distribution Statement A: Approved for public release; distribution is unlimited.

Portions of this effort were performed under contract number NNM05AB50C with the NASA Marshall Space Flight Center. 


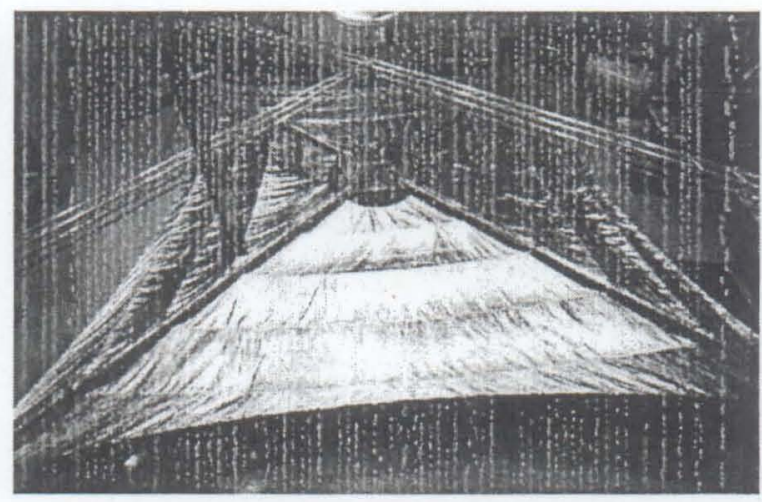

Figure 1. L'Garde 10M System

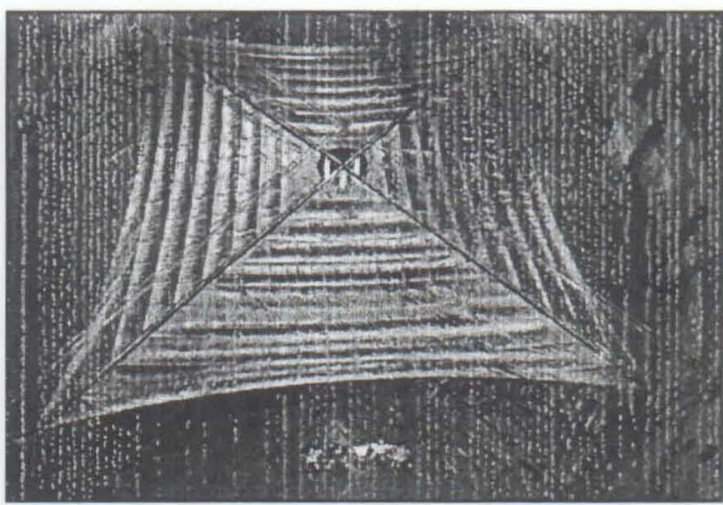

Figure 2. L'Garde 20M System

NASA uses the Technology Readiness Level $(T R L)^{1}$ as one method of judging the maturity of a particular technology and its readiness for infusion into a space application. Higher TRLs are representative of increases in the technology maturity, ranging from initial concept development to flight quality hardware development. TRLs are generally categorized into technology conceptualization and analytical demonstration (Levels 1-2), laboratory technology demonstration, component and analytical model validation (Levels 3-4), and component, subsystem and system demonstrations in a relevant environment (Level 5-6). An initial TRL assessment ${ }^{2}$ was conducted in 2004 to provide a measure of the state of solar sail technology following the 10-meter system tests. This paper will update the TRL assessment to include the 20 meter systems.

The L'Garde design ${ }^{3}$ utilized their patented inflation deployed, sub-Tg rigidized boom with a Kevlar line sun-side truss stiffener system. The sails were constructed from 2 micron aluminum coated Mylar with an integral ripstop feature. The sails transferred loads to the beams through a novel "stripped net" architecture that resulted in a lightweight beam design and low tensile stresses in the sail membrane. The L'Garde design has articulated tip vanes for attitude control. Rotation of the tip vane offsets the location of the center of radiation pressure from the center of mass and induces torques to provide roll, pitch and yaw control. Figure 1 is a photograph of the L'Garde 10 meter system after a successful ambient deployment. Figure 2 is the L'Garde 20 meter system at the Plum Brook $100 \mathrm{ft}$ diameter vacuum chamber. The tip vane is visible in the lower left corner of the photograph.

The ATK team design ${ }^{4}$ utilized their "CoilABLE" mast technology, with its high packing factor and high strength to weight ratio for their primary structural mast elements. The ATK 10-meter quadrant in the LaRC vacuum chamber in shown in Figure 3, and the 20-meter system in the Plum Brook vacuum chamber is shown in Figure 4 . The sails were fabricated by SRS Technologies from 2.5 micron aluminum coated CP1, with a 3-point (mast tips and central

- structural) attachment configuration. The sails were tensioned to provide a nearly flat sail topography. Attitude control is provided by internal mast translating ballast masses and mast tip rotating spreader bars. The ballast masses (2) can translate the entire length of the masts to offset the system center of mass from the center of

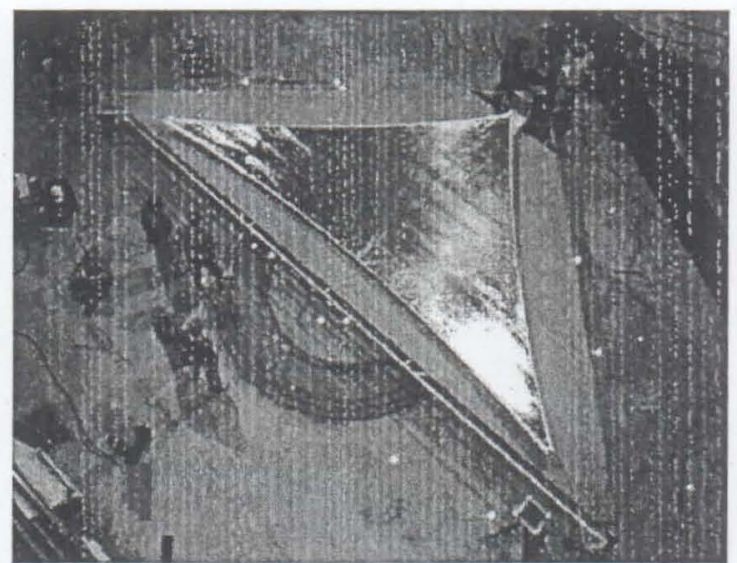

Figure 3. ATK 10M System

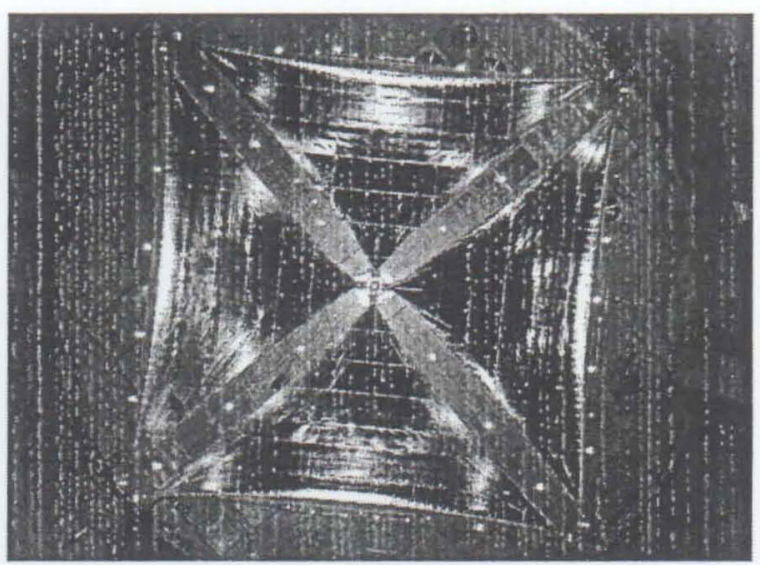

Figure 4. ATK 20M System

pressure and provide pitch and yaw attitude control. The mast tip spreader bars can be rotated to provide a 
"pinwheel" effect roll control for the sail. Micro- pulsed plasma thrusters were also specified in the ATK design for secondary/ backup attitude control.

\section{METER SYSTEM DESIGN MODIFICATIONS}

In addition to the increase in size from 10 meters to 20 meters, numerous design refinements and improvements were applied by both sail development teams during Phase 3 . Components of the L'Garde inflatable booms were improved, including the selection of an alternate material for the boom tip mandrel that improved deployment reliability and addressed leak issues (see Figure 5). Analysis, design and fabrication of an articulated tip vane were included in the L'Garde 20-meter system and are detailed in Figure 6. Line management techniques for the Kevlar truss structure were advanced, including improvements to the truss system spreader bar web configuration, resulting in a more uniform beam deployment sequence. Boom insulation changes were also made after the 10 meter testing.

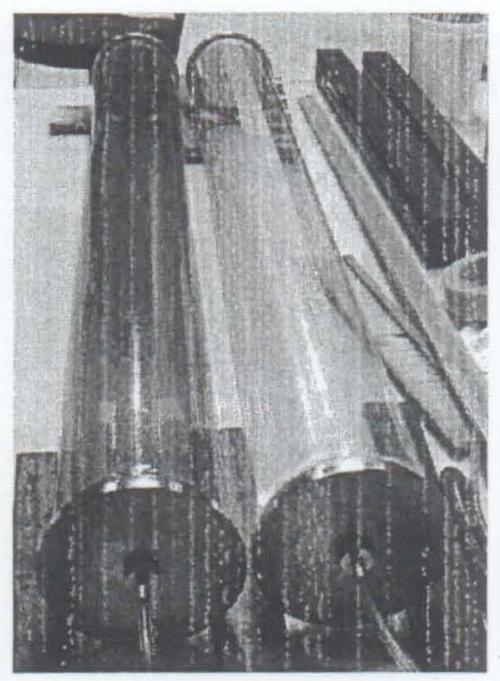

Figure 5. Boom Tip Mandrel Material Improvement

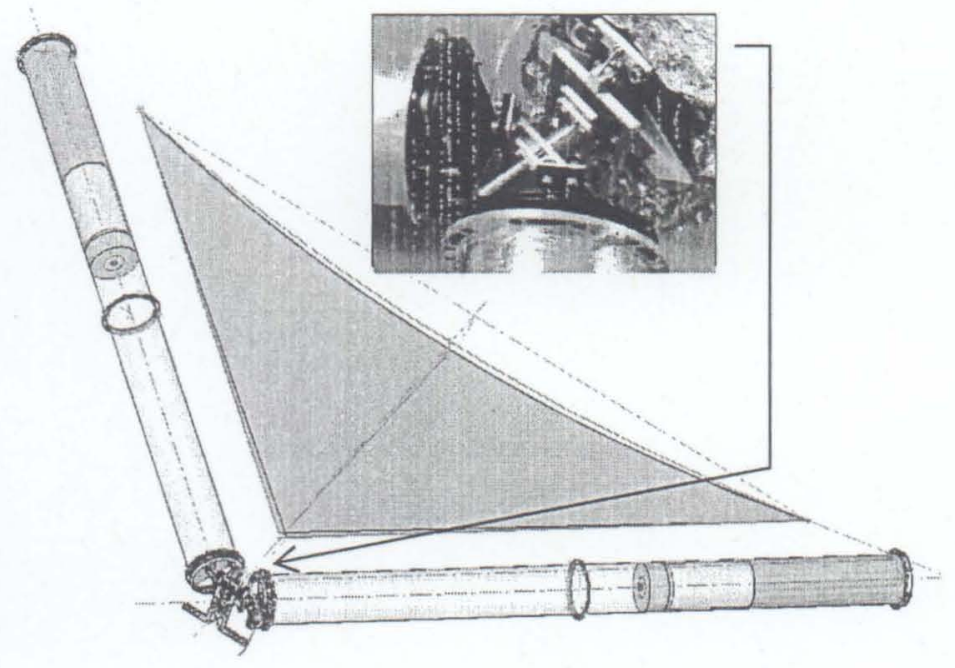

Figure 6. Tip Vane and Tip Vane Mechanism

ATK also implemented design improvements based on "lessons learned" from their 10 meter quadrant system - design and testing in 2004 (Figures 7 and 8). Significant changes were required to implement their attitude control system. A higher fidelity central structure was designed and fabricated to contain the mast deployment mechanisms and ballast mass drive systems. A spreader bar rotation drive mechanism was added to the ends of each mast, including a negator spring system to insure constant tension in the sails during all operational modes. The sail membrane design was refined to increase the total area of the sail, as well as improve the sail corner to halyard
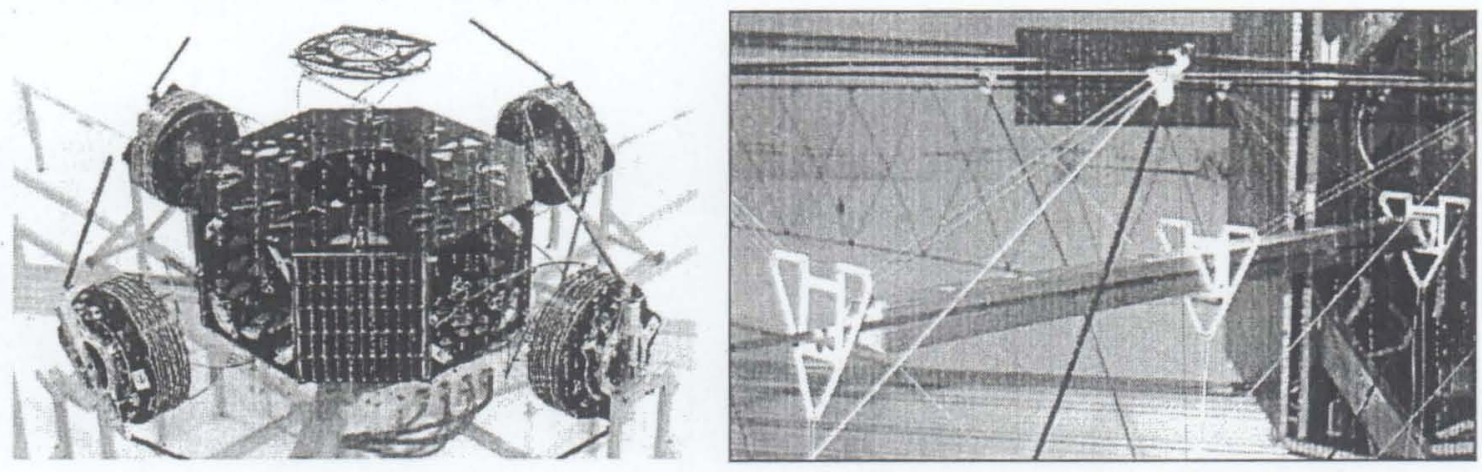

Figure 7. Central Structure and Attitude Control System Design Changes

connection. Sail rip-stop features were added to the final sail quadrant fabricated for the 20 meter testing. Sail folding and rolling techniques were refined and the techniques for proper deployment sequencing of the sail were improved to provide for a smoother sail deployment and reduce the risk of rips and tears during deployment. Minor 
structural refinements were made to the mast corner fittings to increase the reliability of the batten-to-corner group structural attachment.

\section{METER SYSTEM ANALYSIS, TESTING}

Both teams began by designing, fabricating and testing components and subsystems in preparation for full 20 meter system integration and testing. Detailed computational models were created by both teams in order to develop predictions of how each system would perform during performance testing. Detailed test plans and test procedures were prepared and approved by the ISPT office prior to the start of testing. Detailed test success criteria, for each phase of the testing were included in the test plans and procedures. Functional tests were performed to demonstrate form, fit and function. Ambient deployments were performed prior to the high vacuum testing at the GRC Plum Brook Space Power Facility. Since these sails represent the largest ground systems that will be deployed and tested in the world's largest vacuum chamber, a significant effort was made to collect static and dynamic data on the sails and booms with approximately $400 \mathrm{~Gb}$ of data collected, primarily raw photogrammetry data. After the high vacuum deployment tests were completed, sensors, instrumentation and actuators were installed on the test articles to support structural static and dynamic testing. Photogrammetry techniques were utilized to make global and local shape measurements of the sail membranes and beams. A laser vibrometer instrument was also used to gather the
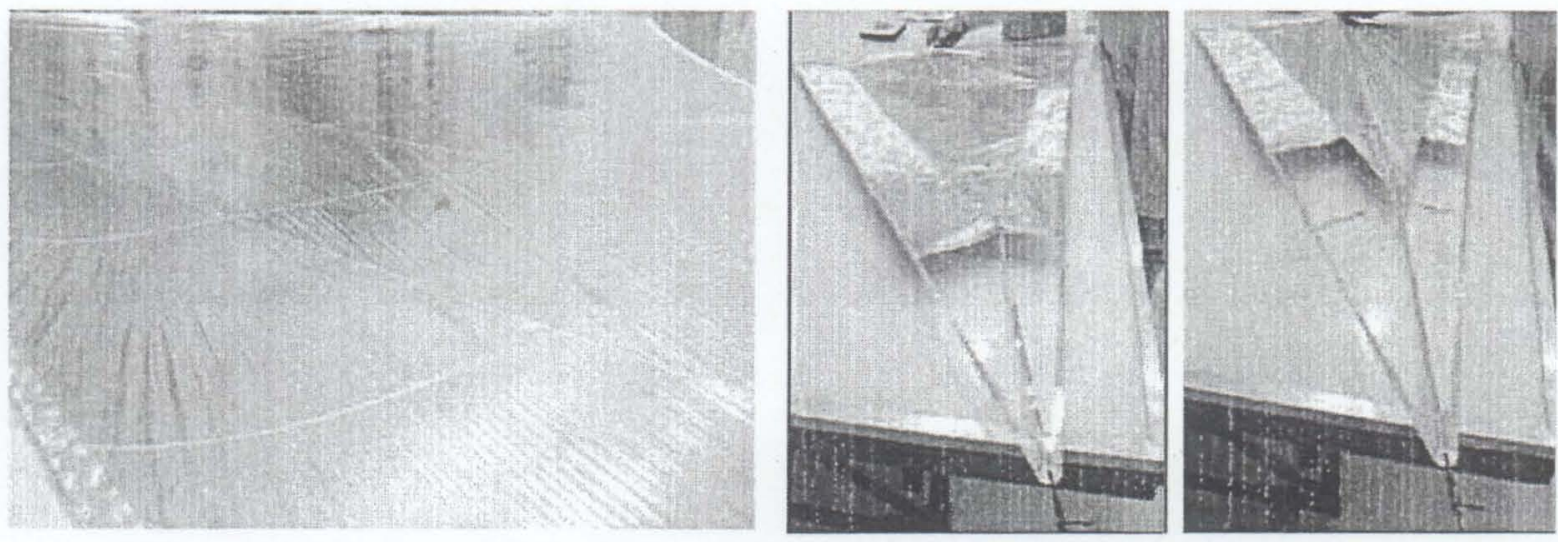

Figure 8. 20-Meter Sail Design Improvements (Ripstop and Sail Corner modifications)

dynamic characteristics of the structures at both ambient pressure and vacuum. Both ATK and L'Garde were able to achieve good correlation between their computational model predictions and the actual hardware performance. In

- addition to functional and structural testing, other analyses and tests were performed during Phase 3, including space environment testing of both the CP1 and Mylar sail membrane materials. Detailed studies were also conducted to analyze the spacecraft charging characteristics of both designs. Technical descriptions of work being performed by ATK $^{5,6,7}$ and L'Garde ${ }^{8,9,10}$ on the 20-meter GSD can be found in the respective team's papers.

\section{TECHNOLOGY READINESS LEVEL ASSESSMENT}

A technical assessment was made of both the L'Garde and ATK 20M SGD sail systems. The assessment addressed TRLs 3-6. The subsystem components of each SGD were assessed from levels $3-5$ and the systems assessment for each SGD was performed at TRL 6 . These assessments were first performed separately by each member of the assessment team. Final scores were agreed upon following detailed discussions and achievement of a consensus within the TRL assessment team. The subsystem and component breakdown for the ATK and L'Garde SGD designs are listed in Table 1. The NMP TRL exit criteria ${ }^{11}$ were applied at each TRL level and an evaluation was performed to determine the completion percentage for a particular TRL level for the listed component, subsystem or system. The maturity of the analytical models and analytical model performance predictions were also judged at the component, subsystem and system levels. As an example, a score of 75 indicates that a particular element is assessed to be $75 \%$ complete for that particular TRL. The assessment of overall relevant environment test compliance is an average of the assessments for on-orbit, launch and ground environments. A total of 8 assessments were performed, consisting of 3 subsystem assessments and 1 system assessment for each of the 2 SGD designs. The TRL assessment conducted after the 10 meter and 20 meter system testing clearly documented that both contractors had demonstrated full attainment of the TRL 3 and 4 requirements. Table 2 below provides a comparison of how well each team demonstrated TRL 5 and 6 after the completion of the 10 meter system testing and the 20 meter system testing. Both teams clearly advanced the state of the art of solar sail technology. 


\begin{tabular}{|c|c|c|}
\hline L'Garde Subsystemi Components & TRLS & $T R L 6$ \\
\hline Boom Components & & $78 \%$ \\
\hline Boom and Rigidization System & $72 \%$ & \\
\hline Inflation Subsystem & $42 \%$ & \\
\hline Heater Wires & $100 \%$ & \\
\hline Insulation & $58 \%$ & \\
\hline End Caps & $100 \%$ & \\
\hline Spreader System and Rings & $75 \%$ & \\
\hline Cat's Cradle & $100 \%$ & \\
\hline Models Replicate Performance & $100 \%$ & \\
\hline Analytical Predictions Complete & $100 \%$ & \\
\hline Sail Components & & $79 \%$ \\
\hline Material \& Coatings & $83 \%$ & \\
\hline Integrated Ripstop & $75 \%$ & \\
\hline Grounding straps & $75 \%$ & \\
\hline Stripped Net & $75 \%$ & \\
\hline Models Replicate Performance & $100 \%$ & \\
\hline Analytical Predictions Complete & $100 \%$ & \\
\hline ACS Components & & $91 \%$ \\
\hline Tip Vanes & $95 \%$ & \\
\hline Vane Cant Mechanism & $95 \%$ & \\
\hline Vane Rotation Mechanism & $100 \%$ & \\
\hline Control Wiring & $100 \%$ & \\
\hline ACS Software & $67 \%$ & \\
\hline Models Replicate Performance & $90 \%$ & \\
\hline Analytical Predictions Complete & $90 \%$ & Hकth \\
\hline Central Structure Components & & $77 \%$ \\
\hline Carrier Assembly & $78 \%$ & \\
\hline Doors \& Actuators & $78 \%$ & maln \\
\hline Spacecraft Interface & $75 \%$ & \\
\hline Models Replicate Performance & $50 \%$ & \\
\hline Analytical Predictions Complete & $75 \%$ & W.1. \\
\hline Model Validation & renty & $63 \%$ \\
\hline $\begin{array}{c}\text { Packing/Flight Design/Interface } \\
\text { Effects Advancement }\end{array}$ & Wum & $81 \%$ \\
\hline
\end{tabular}

\begin{tabular}{|c|c|c|}
\hline ATK Subsystemi Components & TRLS & $\begin{array}{r}T R L \\
+1\end{array}$ \\
\hline Mast Components & & $80 \%$ \\
\hline Battens & $62 \%$ & \\
\hline Longerons & $78 \%$ & \\
\hline Diagonals & $75 \%$ & \\
\hline Corner Groups & $62 \%$ & \\
\hline Halyards & $92 \%$ & \\
\hline Lanyards & $100 \%$ & \\
\hline Deployment Motor/Mechanisms & $92 \%$ & \\
\hline Models Replicate Performance & $100 \%$ & \\
\hline Analytical Predictions Complete & $100 \%$ & \\
\hline Sail Components & & $92 \%$ \\
\hline Material \& Coatings & $100 \%$ & \\
\hline Tear Resistant Design & $67 \%$ & \\
\hline Deployments Sequencers & $95 \%$ & \\
\hline Grounding straps & $100 \%$ & \\
\hline Compliant Border & $100 \%$ & \\
\hline Models Replicate Performance & $91 \%$ & \\
\hline Analytical Predictions Complete & $100 \%$ & \\
\hline ACS Components & & $92 \%$ \\
\hline Translating Masses & $100 \%$ & \\
\hline Translating Mass Motors/ & $100 \%$ & \\
\hline Tip Spreader Bars & $100 \%$ & \\
\hline Mast Tip Mechanism & $100 \%$ & \\
\hline Control Wiring & $100 \%$ & \\
\hline ACS Software & $50 \%$ & \\
\hline Models Replicate Performance & $100 \%$ & \\
\hline Analytical Predictions Complete & $100 \%$ & \\
\hline Central Structure Components & & $82 \%$ \\
\hline Carrier Assembly & $88 \%$ & \\
\hline Doors \& Actuators & $88 \%$ & \\
\hline Spacecraft Interface & $75 \%$ & \\
\hline Drum & $75 \%$ & \\
\hline Models Replicate Performance & $88 \%$ & \\
\hline Analytical Predictions Complete & $88 \%$ & 4 \\
\hline Model Validation & \multirow{2}{*}{ (1) } & $88 \%$ \\
\hline $\begin{array}{l}\text { Packing/Flight Design/Interface } \\
\text { Effects Advancement }\end{array}$ & & $84 \%$ \\
\hline
\end{tabular}

Table 1. 20M System TRL 5 and TRL 6 Assessment Results

\begin{tabular}{|l|c|c|c|c|}
\hline Vendor & $\begin{array}{c}\frac{\text { Post 10M }}{\text { TRL 5 }} \\
\text { Completion } \\
\text { Average }\end{array}$ & $\begin{array}{c}\frac{\text { Post 20M }}{\text { TRL 5 }} \\
\text { Completion } \\
\text { Average }\end{array}$ & $\begin{array}{c}\frac{\text { Post 10M }}{\text { TRL 6 }} \\
\text { Completion } \\
\text { Average }\end{array}$ & $\begin{array}{c}\frac{\text { Post 20M }}{\text { TRL 6 }} \\
\text { Completion } \\
\text { Average }\end{array}$ \\
\hline ATK & $76 \%$ & $89 \%$ & $60 \%$ & $86 \%$ \\
\hline L'Garde & $75 \%$ & $84 \%$ & $68 \%$ & $78 \%$ \\
\hline
\end{tabular}

Table 2. TRL 5 and TRL 6 Comparison 
Table 3 below provides a detailed explanation of the gaps identified after the 10 meter testing and provides an update to the impact of the technology as a result of the 20 meter development and testing.

\section{Table 3. Solar Sail Technology Gap Analysis Results}

\begin{tabular}{|c|c|c|}
\hline $\begin{array}{l}\text { No molar Sail Technology Gaps } \\
\text { deployment dynamics has been done. }\end{array}$ & $\begin{array}{l}\text { Deployment dynamics could } \\
\text { impact the design and operation of } \\
\text { a solar sail system, which could } \\
\text { cause significant design changes. } \\
\text { Significant design changes could } \\
\text { invalidate previous model } \\
\text { validation efforts. }\end{array}$ & $\begin{array}{l}\text { - ATK had accelerometers on their tips for } \\
\text { deployment and L'Garde used } \\
\text { photogrammetry and video to view boom } \\
\text { tips. } \\
\text { - L'Garde experienced asymmetric deployment } \\
\text { issues during vacuum testing. Maintaining } \\
\text { attitude control and stability during } \\
\text { deployment is critical and L'Garde bas } \\
\text { conducted an initial deployment simulation } \\
\text { tool. Based on the 20-m system }\end{array}$ \\
\hline $\begin{array}{l}\text { Materials environmental testing is } \\
\text { incomplete or in some cases has not } \\
\text { been done at all. No testing has been } \\
\text { done on seams, bonds, adhesives, } \\
\text { ground straps, ripstop, sequencers, } \\
\text { targets, inflatable booms or graphite } \\
\text { epoxy components. }\end{array}$ & $\begin{array}{l}\text { Results of materials testing could } \\
\text { necessitate materials changes and } \\
\text { impact design. }\end{array}$ & $\begin{array}{l}\text { - Ground System Demonstrator (GSD) material } \\
\text { testing has been done in support of I1 } \\
\text { Diamond (.95 AU) and Solar Polar Imager (.5 } \\
\text { AU), considered to be the Initial Application } \\
\text { Missions (IAM). } \\
\text { - Additional testing that was done on the } \\
\text { L'Garde sail material indicates an issue with } \\
\text { coated Mylar in a VUV environment. } \\
\text { Material loses strength in } 3 \text { years and } \\
\text { disintegrates in a } 6 \text { years. Final analyses of } \\
\text { the test results are underway. } \\
\text { - No testing has been done to date on seams, } \\
\text { booms, beams, targets, repairs or elements. }\end{array}$ \\
\hline $\begin{array}{l}\text { Meteoroid/orbital debris (M/OD) testing } \\
\text { has been very limited. M/OD testing } \\
\text { should be done with the integrated } \\
\text { ripstop. }\end{array}$ & $\begin{array}{l}\text { The functionality of ripstop has not } \\
\text { been tested or proven. Tear } \\
\text { resistance is imperative to a good } \\
\text { flight design. }\end{array}$ & $\begin{array}{l}\text { - Limited ATK ripstop testing done by SRS. } \\
\text { - L'Garde ripstop demonstrated during } \\
\text { deployment testing. } \\
\text { - L'Garde boom insulation needs investigation. } \\
\text { MOD impact on boom rigidity could be an } \\
\text { issue. }\end{array}$ \\
\hline $\begin{array}{l}\text { Scalability between the } 10 \mathrm{~m} \text { and } 20 \mathrm{~m} \\
\text { designs is in question due to the design } \\
\text { changes occurring after the } 10 \mathrm{~m} \text { system } \\
\text { testing was complete. }\end{array}$ & $\begin{array}{l}\text { Significant design changes, as well } \\
\text { as the inclusion of the attitude } \\
\text { control system in the } 20 \mathrm{~m} \text { design, } \\
\text { impacts the ability to assess the } \\
\text { scalability between the } 10 \mathrm{~m} \text { and } \\
20 \mathrm{~m} \text { designs. The process for } \\
\text { evaluating model scaling has not } \\
\text { been established. Scalability } \\
\text { between ground demos needs to be } \\
\text { established so that models can } \\
\text { validate and then used to support } \\
\text { much larger flight designs. }\end{array}$ & $\begin{array}{l}\text { - Data on model scalability between the } 10 \text { and } \\
20 \mathrm{M} \text { systems is TBD. } \\
\text { - The sensitivity of the sail models to design } \\
\text { changes has not been determined. }\end{array}$ \\
\hline $\begin{array}{l}\text { Scalability to a science mission needs to } \\
\text { be studied in detail. Facilities do not } \\
\text { exist to manufacture, assemble or test a } \\
\text { large-scale sail system. Current } \\
\text { manufacturing and assembly processes } \\
\text { for the most part are manual and labor } \\
\text { intensive. }\end{array}$ & $\begin{array}{l}\text { Feasibility of manufacturing a } 10- \\
20 \mathrm{~m} \text { design has been proven but the } \\
\text { processes and facilities to } \\
\text { manufacture a much larger flight } \\
\text { system have not been proven. } \\
\text { Current facilities and techniques } \\
\text { appear to be inadequate to handle a } \\
\text { larger sail system and fabrication } \\
\text { scalability has not been proven. } \\
\text { New techniques, processes, and } \\
\text { facilities need to be developed for a } \\
\text { larger sail system. A rigorous } \\
\text { study should be conducted to look } \\
\text { at all of the factors involved in } \\
\text { fabricating, assembling and testing } \\
\text { a larger sail. }\end{array}$ & $\begin{array}{l}\text { - Limited additional information between the } \\
10 \mathrm{M} \text { and } 20 \mathrm{M} \text { ground demonstrator systems. } \\
\text { - An assessment of facilities for ambient } \\
\text { deployment was conducted by ISPT with } \\
\text { several sites identified. } \\
\text { - ATK has developed a beam/longeron splice } \\
\text { technique. } \\
\text { - L'Garde has manufactured booms up to } 50 \mathrm{~m} \text { in } \\
\text { length for another program }\end{array}$ \\
\hline
\end{tabular}




\begin{tabular}{|c|c|c|}
\hline Wolar Sail Technology Gaps & Post 10M System Impacts & W' 20M System Gap Update \\
\hline $\begin{array}{l}\text { The manufacturing and assembly } \\
\text { process is still evolving and there were } \\
\text { problems with manufacturing and } \\
\text { assembling the } 10 \mathrm{~m} \text { systems that are not } \\
\text { completely understood. The } \\
\text { manufacturing and assembly processes } \\
\text { are still in development and are not well } \\
\text { documented. }\end{array}$ & $\begin{array}{l}\text { If problems in the } 10 \text { and } 20 \mathrm{~m} \\
\text { process are not thoroughly } \\
\text { understood then processes for } \\
\text { manufacturing and assembling } \\
\text { larger sail systems could be } \\
\text { impacted. }\end{array}$ & $\begin{array}{l}\text { - Problems with fabrication and assembly } \\
\text { processes still persist and were evident during } \\
\text { the } 20 \mathrm{~m} \text { ground demonstration testing. } \\
\text { - Processes and procedures are not well } \\
\text { documented. } \\
\text { - Reliability and repeatability of the } \\
\text { manufacturing and assembly processes are an } \\
\text { issue. } \\
\text { - Process are highly labor intensive and } \\
\text { personnel training is critical. (i.e. boom } \\
\text { assembly persons cannot reliably perform sail } \\
\text { assembly functions) } \\
\text { - Mandatory inspection points and QC are not in } \\
\text { place. } \\
\text { - Problems and issues with the } 20 \mathrm{~m} \text { testing have } \\
\text { in some cases not been fully investigated or } \\
\text { resolved. } \\
\text { - Process changes by the vendors are not visible } \\
\text { to the contractors or to NASA. } \\
\text { - Problems occurred with the } 20 \mathrm{M} \text { system, (for } \\
\text { both L'Garde \& ATK) during stowing and } \\
\text { assembly. } \\
\text { - For L'Garde, inspection of line management is } \\
\text { critical but difficult and labor intensive. The } \\
\text { risk probability of misrouting lines is great } \\
\text { and the problem can cause damage to the sail, } \\
\text { stripped net, insulation, cats' cradle and the } \\
\text { tip. Greater than } 500 \text { inspection points for a } \\
\text { 20M system. } \\
\text { - For ATK, inspection of longerons and battens } \\
\text { are critical and mandatory. More than } 700 \\
\text { batten to corner group adhesive bonds are in a } \\
20 \mathrm{M} \text { system. Three batten bond failures } \\
\text { occurred and repairs were made with metallic } \\
\text { straps. } \\
\text { - ATK has identified but not implemented a } \\
\text { nondestructive inspection technique to } \\
\text { identify flaws in longerons and battens. }\end{array}$ \\
\hline $\begin{array}{l}\text { Current sail materials can not be } \\
\text { fabricated, assembled or tested without } \\
\text { rips and tears. The causes of rips and } \\
\text { tears are not fully understood or } \\
\text { defined. The full impact of rips and } \\
\text { tears on a flight system have not been } \\
\text { studied or documented. Is a rip or tear } \\
\text { acceptable and to what degree is it } \\
\text { acceptable? }\end{array}$ & $\begin{array}{l}\text { Tears or rips could impact } \\
\text { deployment and operation of a sail } \\
\text { flight system. The impacts of tears } \\
\text { or rips could change the design, } \\
\text { which could impact model } \\
\text { validation of the current system and } \\
\text { impact sail propulsion. }\end{array}$ & $\begin{array}{l}\text { - L'Garde and ATK have performed an analysis } \\
\text { of the impacts rips and tears have on } \\
\text { propulsion (Cp/Cm shifts). } \\
\text { - Both contractors had rips and tears during the } \\
20 \mathrm{M} \text { assembly and testing. } \\
\text { - Repair procedures have been developed but } \\
\text { repairs have not been tested. Testing of } \\
\text { repairs on a flight article may not be possible } \\
\text { and inspection methods for repairs bave not } \\
\text { been developed. }\end{array}$ \\
\hline $\begin{array}{l}\text { Thermal analysis and testing of solar } \\
\text { sail systems are very limited or non- } \\
\text { existent. The affect of thermal cycles } \\
\text { on the materials and on the system is } \\
\text { unknown. Temperature differences } \\
\text { between the sun side and the space side } \\
\text { of gossamer structures are not known. }\end{array}$ & $\begin{array}{l}\text { Thermal analyses and testing could } \\
\text { impact the design and thus impact } \\
\text { model validation. Further } \\
\text { evaluation of the thermal effects } \\
\text { should be studied. }\end{array}$ & $\begin{array}{l}\text { - The thermal environment identified for the } 20 \mathrm{~m} \\
\text { SGD was .5-1 AU. } \\
\text { - No new thermal analysis has been presented to } \\
\text { date. } \\
\text { - The thermal impacts of tears, gaps and/or MOD } \\
\text { holes on the rigidity of the sub-Tg booms, for } \\
\text { L'Garde, are not known. Insulation tears and } \\
\text { gaps were a major issue during the } 20 \mathrm{~m} \\
\text { deployment test. }\end{array}$ \\
\hline $\begin{array}{l}\text { No shock testing or analysis has been } \\
\text { done. Both SGD designs have } \\
\text { hardware mounted at the end of the } \\
\text { beams/booms and the impact of shock } \\
\text { testing needs to be analyzed. }\end{array}$ & $\begin{array}{l}\text { The shock environment could } \\
\text { damage hardware. Analyses and } \\
\text { testing as appropriate should be } \\
\text { performed to evaluate shock } \\
\text { events. }\end{array}$ & $\begin{array}{l}\text { - No shock analysis or testing has been } \\
\text { performed. Additional mass was added to the } \\
\text { beam/boom tips for the } 20 \mathrm{~m} \text { designs for both } \\
\text { L'Garde and ATK. The } 20 \mathrm{~m} \text { SGDs were } \\
\text { shipped across country with no issues. }\end{array}$ \\
\hline
\end{tabular}




\section{Solar Sail Technology Gaps $/$ Post 10M System Impacts}

There is no verifiable inspection and/or monitoring system for fabrication, assembly and testing of sails. The stresses induced in the sail material during these processes are unknown. Maintaining positive stress margins for flight sails could be an issue.

An automatic inspection system for monitoring material thickness, coating density and uniformity has not been developed. This could be an issue for large scale sails. Current methods of random testing at the ends of rolls may or may not be adequate for larger systems.

A perfect/flawless sail my not be possible to manufacture and handle without damage. Repair methods have been developed but no testing has been done on the sail repairs. Are the repairs adequate? Do the repairs last? What are the impacts on the surrounding film and coating? Are repair areas more susceptible to environmental problems (temperature extremes, VUV, plasma, M/OD, etc.)?

The mounting configuration of telemetry systems and/or other instruments, for a flight sail system, could be impacted by the Solar Sail noise in the $L 1$ environment.

The charging analysis is incomplete and testing is limited or non-existent. control system could be an issue. Insufficient analysis has been done for the attitude control system.
If the sails can not be manufactured and assembled with known induced stresses then positive stress margins can not be assured. Positive stress margins must be maintained for flight hardware to be viable.

This could impact sail design for larger sails which could impact model validation.

The performance of sail repair is unknown. The current techniques of fabrication, assembly and testing are not adequate to prevent tears and rips. The impacts of tears and rips in a flight system could affect system performance and operation.

Telemetry or science data could be impacted.

This could impact the design of the sail system. Charging could also be an issue during deployment (ground and space) and during long-term operation. of a sail system.

The current design could be inadequate to meet stability requirements. This may be addressed sufficiently in the $20 \mathrm{~m}$ design. An evaluation of this will be made when the $20 \mathrm{~m}$ design is complete.

Test data may be inaccurate which could impact model validation.

\section{M System Gap Update}

- No progress has been made on this issue for the sail fabric. This is a major issue. Fatigue and stress on sail fabric is a problem. Repairs are a particular concern due to the potential of creating stress concentrations.

- Coating density was an issue for both ATK

- Sail material density (CP1 \& Mylar) was an issue. ATK visually inspected the sail material prior to coating and removed unacceptable material but this is a manual process. No automatic inspection system exists.

- L'Garde $20 \mathrm{~m}$ coating was non-uniform with bare Mylar exposed. This could pose a risk as Mylar is susceptible to UV radiation.

- ATK has test records of sail thickness and optical properties. Records for L'Garde have not been presented.

- Repairs were made on both $20 \mathrm{M}$ SGDs. No progress on this issue. Repairs have not been thoroughly tested.

- Folding stresses on repairs are a potential issue. Folding stresses on an edge cord were identified as a potential cause of a large sail rip during the ATK $20 \mathrm{~m}$ testing.

- For a flight project, extra sails and sail fabric need to be fabricated.

- No progress since this is a mission specific constraint.

- A charging analysis bas been completed for .5$1 \mathrm{AU}$ environment. Front-to-back and side-toside conductive sail material will be required. Both Mylar and CP1 were found to be acceptable.

- ATK demonstrated a sliding ballast mass and spreader bar ACS system during the $20 \mathrm{~m}$ testing. The full range of motion was tested. An analysis by Arizona State University was performed.

- L'Garde tested a single, subscale tip vane ACS system. The modeling of the ACS, and hardware in the loop testing has been done for the $20 \mathrm{~m}$ system. The current ACS designs are for the .5-1 Au environment.

Testing the sail in an ambient environment could be an issue with $20 \mathrm{~m}^{+}$sail systems. The facility environment must be measured and known before sail tests can be conducted. Air currents or ground vibrations could affect the test results if they are not known and monitored during the test.
- Facilities for testing or deployment of a sail larger than $20 \mathrm{~m}$ in a vacuum do not currently exist. Condensation of moisture onto the sail during pump down was identified as another concern associated with vacuum testing.

- Facilities for ambient deployment of larger sails have been identified. A critical aspect of these facilities is that they can be well insulated to reduce the impact of thermal air currents on the sail membranes. 


\begin{tabular}{|c|c|c|}
\hline Solar Sail Technology Gaps & Post 10M System Impacts & 20M System Gap Update \\
\hline $\begin{array}{l}\text { Installation of sensors (thermocouples, } \\
\text { strain gauges, targets, etc.) on thin films } \\
\text { is an issue for testing and on orbit } \\
\text { monitoring. Current processes are } \\
\text { inadequate to address this issue. }\end{array}$ & $\begin{array}{l}\text { The technology development of } \\
\text { sensors and the process of attaching } \\
\text { them to thin films should be } \\
\text { assessed. This could impact the } \\
\text { design and the ability to validate } \\
\text { model results or monitor sail } \\
\text { systems in space. }\end{array}$ & $\begin{array}{l}\text { - No progress was made for sensors on thin } \\
\text { films. } \\
\text { - ATK deployed and tested with accelerometers, } \\
\text { piezoelectric actuators and strain gauges on } \\
\text { the beams and targets embedded in the sail. . } \\
\text { - L'Garde did not have sensors during testing and } \\
\text { they have never deployed with targets on the } \\
\text { sail. Due to the boom design, sensor } \\
\text { installation could be an issue for L'Garde. }\end{array}$ \\
\hline $\begin{array}{l}\text { An analysis of life and survivability } \\
\text { should be performed for a sail system. } \\
\text { How many times can a sail system be } \\
\text { deployed and tested without using up } \\
\text { too much life margin? }\end{array}$ & $\begin{array}{l}\text { Sail life/survivability margin can be } \\
\text { diminished during the fabrication, } \\
\text { assembly and test processes. } \\
\text { Current processes and techniques } \\
\text { do not monitor stresses induced on } \\
\text { the sail or structure. Current } \\
\text { monitoring and inspection process } \\
\text { is inadequate or non-existent. } \\
\text { Damage can be done to the sail } \\
\text { during these processes. }\end{array}$ & $\begin{array}{l}\text { - No analysis or additional life testing has been } \\
\text { done and the monitoring and inspection } \\
\text { process have not improved. As the sail } \\
\text { increases in size the scope of this problem } \\
\text { will increase. } \\
\text { - During the 20M SGD, ATK performed multiple } \\
\text { deployments (beams > } 15 \text { times and sail } \\
\text { quadrants } 2-9 \text { times) and L'Garde deployed } \\
\text { one boom } 5 \text { times and the system } 2 \text { times. } \\
\text { - The L'Garde inflation system design (and } \\
\text { especially the leaking of the tip mandrels) is a } \\
\text { potential life issue. } \\
\text { - No analysis has been performed on limited life } \\
\text { items or how long the sails can be folded } \\
\text { before inducing potential problems. The life } \\
\text { of a pristine sail isn't known, much less the } \\
\text { life of a tested sail. } \\
\text { - ATK longerons are susceptible to nicks which } \\
\text { lead to fractures due to the high strain energy } \\
\text { of the stowed system. }\end{array}$ \\
\hline $\begin{array}{l}\text { No attitude control software/algorithms } \\
\text { have been written or tested. }\end{array}$ & $\begin{array}{l}\text { The } 20 \mathrm{~m} \text { design will implement an } \\
\text { initial version of attitude control } \\
\text { algorithms that will be evaluated } \\
\text { when complete. The design and } \\
\text { implementation of an attitude } \\
\text { control system could impact system } \\
\text { design. }\end{array}$ & $\begin{array}{l}\text { - Attitude control systems (ACS) for both } \\
\text { L'Garde and ATK were developed and } \\
\text { demonstrated to some degree during the } 20 \\
\text { SGD. } \\
\text { - Complete range of motion and translation/ } \\
\text { rotation rates were demonstrated by ATK } \\
\text { during the } 20 \mathrm{~m} \text { testing. } \\
\text { - L'Garde performed range of motion and rate } \\
\text { testing with a subscale ACS. } \\
\text { - Attitude maneuvers have been modeled (S5 \& } \\
\text { PSS) and proven for both systems for typical } \\
\text { L1 diamond and SPI missions. }\end{array}$ \\
\hline $\begin{array}{l}\text { One of the designs assumes that the } \\
\text { central structure and deployment } \\
\text { subsystems will jettisoned after on-orbit } \\
\text { deployment of the masts and sails. No } \\
\text { modeling has been done of system } \\
\text { dynamic impacts during jettison events. }\end{array}$ & $\begin{array}{l}\text { The jettison event could be a driver } \\
\text { for the dynamics of a deployed sail } \\
\text { system. If the impacts are not } \\
\text { known, anomalies could be } \\
\text { introduced and the design could be } \\
\text { affected. Analysis and testing need } \\
\text { to be done to understand the } \\
\text { impacts. }\end{array}$ & $\begin{array}{l}\text { - Models, analysis and testing need to be done on } \\
\text { the dynamic impacts to a deployed sail of } \\
\text { mass jettison on orbit. }\end{array}$ \\
\hline $\begin{array}{l}\text { The current boom inflation system for } \\
\text { L'Garde is a GSE system. A flight or } \\
\text { flight-like design for an inflation system } \\
\text { has not been done. Inflation systems } \\
\text { have been used in space numerous } \\
\text { times, but the design of the inflation } \\
\text { system for a flight project could impact } \\
\text { the current L'Garde system design. }\end{array}$ & & $\begin{array}{l}\text { - Non flight like design was tested for the } 20 \mathrm{M} \\
\text { SGD. } \\
\text { - No analysis of the tank size and the gas } \\
\text { required has been presented. } \\
\text { - Issues were noted with mandrel leaks and their } \\
\text { impacts during deployment. } \\
\text { - Issues were noted in vacum with asymmetric } \\
\text { deployments due to the inflation system. } \\
\text { - Over pressurization of booms can cause a } \\
\text { critical failure and burst the booms. The } \\
\text { current inflation control system and sensors } \\
\text { are inadequate to prevent this problem. } \\
\text { - The impact of venting on sail dynamics is not } \\
\text { known. }\end{array}$ \\
\hline
\end{tabular}




\section{Potential Future Tasks}

Shortfalls and gaps identified as a result of the TRL assessment included the following: 1) more detailed deployment dynamics modeling, 2) additional environmental testing of sail and boom materials, 3) manufacturing and assembly process issue resolutions, 4) design and manufacturing scalability issues, 5) additional charging and plasma interaction analysis and testing, and 6) design and demonstration of an attitude control system, including algorithm/ software development. The top-level, sequential logic for performance of these "gap closure" tasks is identified in Figure 9. Inputs to the process would be the results of the ground system demonstration work recently completed, as well as science mission requirements for the Heliostorm Mission.

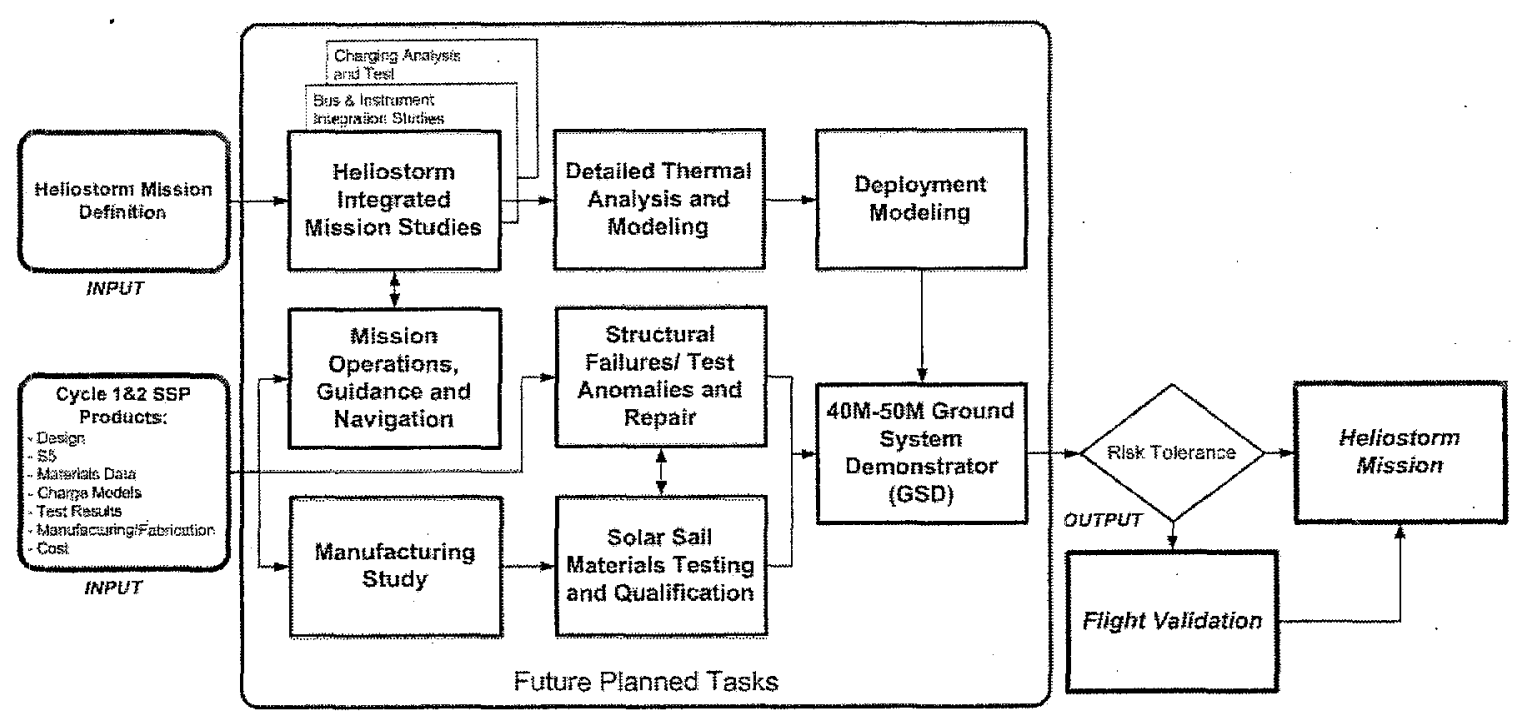

Figure 9. Potential Future Tasks, Top-Level Flowchart

Descriptions of the Tasks identified in Figure 9 are listed below:

- The objective of the "Heliostorm Integrated Mission Studies" task will be to perform a comprehensive conceptual study of the Heliostorm mission including satellite bus requirements, bus system interfaces, science instrument requirements, and an analysis of the attitude control system performance requirements.

- The "Mission Operations, Guidance and Navigation" task will perform design, analysis and trade studies of potential solar sail propulsion science missions, such as Heliostorm, Solar Polar Imager and the Interstellar Probe. Particular emphasis will be on the requirements and performance of the solar sail guidance, navigation and control system.

- The goal of the "Manufacturing Study" task will be to assess the manufacturability of large scale solar sails (100 160 meter), with emphasis on the identification of manufacturing technologies development and other fabrication, assembly and inspection requirements.

- The "Detailed Thermal Analysis and Modeling" task will develop thermal models of solar sails to predict the performance of large scale solar sails in a relevant natural environment.

- The objective of the "Deployment Modeling" task will be to develop mathematical models of solar sail deployment in order to perform a rigorous analysis of deployment mechanics, loads and environments.

" The "Structural Failures/ Test Anomalies and Repair" task will assess the causes and effects of solar sail material rips and tears and develop corrective actions and prevention methods.

" The objective of the "Solar Sail Materials Testing and Qualification" task will be to perform more comprehensive, long-duration, combined environment testing of all solar sail materials (sail membranes, seams, bonds, adhesives, ripstop, booms, sequencers, mast materials and repair materials).

- The objective of the "40M-50M Ground System Demonstrator" task will be to demonstrate the scalability of manufacturing processes and deployment concepts for larger scale solar sails.

Completion of these tasks could lead directly to a solar sail flight validation mission, followed by the performance of the Heliostorm mission, enabled by the development of solar sail propulsion technology. 


\section{ACKNOWLEDGMENTS}

This work was funded in whole or in part by the In-Space Propulsion Technology Program, which is managed by NASA's Science Mission Directorate in Washington, D.C. The program objective is to develop in-space propulsion technologies that can enable or benefit near and mid-term NASA space science missions by significantly reducing cost, mass or travel times.

\section{REFERENCES}

1. Mankins, J., "Technology Readiness Levels, A White Paper", April 6, 1995, NASA.

2. "Assessment of Technology Readiness for Solar Sail Technology Area", In-Space Propulsion Technology Projects Office, December 2004.

3. Lichodziejewski, D., Derbès B., Galeana, D, Friese, D., Vacuum Deployment and Testing of a 4- Quadrant Scalable Inflatable Rigidizable Solar Sail System 46th AIAA/ASME/ASCE/AHS/ASC Structures, Structural Dynamics \& Materials Conference, Austin, TX, AlAA-2005-2121, Apr 18-21, 2005

4. Murphy, D., et al, Validation of a Scalable Solar Sailcraft, Paper No. TBD, 53rd JANNAF Propulsion Meeting / 1st SC Propulsion Subcommittee Joint Meeting, Monterey, CA, December 5-8, 2005.

5. Gaspar, J. et al.,"Testing Of A 20-Meter Solar Sail System", 53rd JANNAF Propulsion Meeting, December 2005

6. Taleghani, T. et al., "20 Meter Solar Sail Analysis and Correlation", 53rd JANNAF Propulsion Meeting, December 2005

7. Laue, G., Case, D. and Moore, J., "Fabrication and Deployment Testing of Solar Sail Quadrants for a 20-meter Solar Sail Ground Test System Demonstration", 41st AIAA Joint Propulsion Conference, July 2005, AIAA 2005-3930

8. Lichodziejewski, D., et al., "Vacuum Deployment and Testing Of a 20 meter Solar Sail System", 47th AIAA/ASME/ASCE/AHS/ASC Structures, Structural Dynamics, and Materials Conference, May 2006, AIAA 20061705

9. Sleight, D., et al., "Structural Analysis and Test Comparison of a 20-Meter Inflation-Deployed Solar Sail", 47th AIAA/ASME/ASCE/AHS/ASC Structures, Structural Dynamics, and Materials Conference, May 2006, AIAA 20061706

10. Mann T., et al., "Ground Testing A 20-Meter Inflation Deployed Solar Sail", 47th AIAA/ASME/ASCE/AHS/ASC Structures, Structural Dynamics, and Materials Conference, May 2006, AIAA 2006-1707

11. "New Millennium Program (NMP) Technology Readiness Levels for the New Millennium Program - Version 1", May 22, 2003, New Millennium Program Office. 